\title{
12
}

\section{The Millennial Learner: Challenges and Opportunities}

\author{
Saundra Y. McGuire \\ Louisiana State University
}

\section{Dennis A. Williams \\ Georgetown University}

Students enrolled in college today are, in many respects, quite different from students enrolled a fere decades ago. Learners today seem more focused on being credentialed, and less concerned with obtaining a broad-based, liberal arts education. Today's faculty may find it challenging to provide engaging learning activities for this generation of students. Millennial educators must instill in students a desire to think critically and provide them with strategies that will make them more efficient learners. Campus learning centers and faculty development centers can work together to foster an academic climate that belps all students to realize their full academic potential.

\section{INTRODUCTION}

The term "millennial learner" can take on a wide variety of meanings. For the purposes of this chapter, however, a millennial learner is defined as 1) a student of traditional college age (17-24) and 2) a student who is attending college in the year 2001 or beyond.

In discussing the challenges and opportunities presented by the millennial learner, this chapter focuses on three characteristics which are contrasted with corresponding characteristics of learners in the 1970s. These comparisons are offered as generalizations; neither group is monolithic. However, the majority of learners in each group are associated with 
the dominant characteristics assigned to the group. The three contrasting characteristics are their attitudes about acquiring a degree, their access to and utilization of computers, and their tolerance for nonengaging pedagogical techniques (Braxton, Milem, \& Sullivan, 2000).

Table 12.1 is based on the authors' combined 60 years of experience teaching college students and assisting them in developing learning strategies. The term "producer mentality" refers to the general expectation that the student must produce a quality product before a satisfactory grade can be assigned for work performed. The term "consumer mentality" refers to the expectation that if tuition and fees are paid, a degree will be granted. Additionally, the students (consumers) must be kept satisfied during the process.

The ubiquitous presence of computers on today's campuses is unparalleled. In the 1970s, it was unlikely that any students other than computer science majors would have free access to computers on a regular basis. Today, however, if the residence halls on campus are not wired for 24 hour Internet access, many students and parents are likely to look elsewhere for college enrollment. Furthermore, it is the authors' experience that students today are more likely to require active learning strategies to keep them focused on educational pursuits than were the students in the 1970s.

TABLE 12.1

Characteristics of 1970 s Learners and Millennial Learners

\begin{tabular}{ll}
\hline 1970s Leamers & Millennial Leamers \\
\hline Producer mentality & Consumer mentality \\
Very limited computer access & Ubiquitous computer access \\
$\begin{array}{l}\text { Tolerant of nonengaging } \\
\text { pedagogical techniques }\end{array}$ & $\begin{array}{l}\text { Intolerant of nonengaging } \\
\text { pedagogical techniques }\end{array}$ \\
\hline
\end{tabular}

For purposes of comparison, a contrast is also made between three characteristics of the typical millennial faculty member and the typical faculty member of the 1970s (Table 12.2) (Sax, Astin, Korn, \& Gilmartin, 1999). 
TABLE 12.2

Characteristics of 1970s Faculty and Millennial Faculty

\begin{tabular}{ll}
\hline 1970s Faculty & Millennial Faculty \\
\hline App. 25 years older than students & App. 30 years older than students \\
Uses primarily lecture format & Uses primarily lecture format \\
$\begin{array}{l}\text { Knows little about learning } \\
\text { mechanisms and strategies }\end{array}$ & $\begin{array}{l}\text { Knows little about learning } \\
\text { mechanisms and strategies }\end{array}$ \\
\hline
\end{tabular}

It is apparent that the millennial learners typically are quite different from their 1970s counterpart, but the millennial faculty members are very similar, at least with respect to the three characteristics listed.

\section{Student and Faculty Gaps}

The characteristics of the millennial learner provide special challenges for educators, but also special opportunities. There is currently a very large gap between faculty expectations of student behavior and actual student behavior. Students entering their first-year of college at Miami University reported that they had studied about an hour a day outside of class during high school (Schilling \& Schilling, 1999). These same students, however, expected to spend 30-40 hours a week in academic pursuits in college, including class attendance. College faculty members expected students to spend two to three hours outside of class for every hour spent in class. This represents a significant gap between professors' expectations of the requirements for student success and the students' expectations for their own success. Even more dramatic was that the time students actually spent studying was significantly less than their own expectations. Many students actually spent 20 or fewer hours per week on academic work, including class attendance.

In addition to the expectation gap, there is a communication gap between millennial students and faculty. This gap is in large part due to the age difference between the two groups. According to the Office of Budget and Planning at Louisiana State University (LSU), the average age of full-time instructional faculty is 47.2 years, and the average age of LSU undergraduate students is 21.6 years. Faculty members are likely to have begun their teaching careers in the 1970s or early 1980s, and have expectations set by their experiences in those decades. However, today's faculty members are increasingly forced to deal with such situations as cell 
phones and pagers ringing in the middle of a lecture, or students IMing (instant messaging) each other during a computer class.

This communication gap also extends to the communication of learning tasks. If a faculty member assigns a paper with the expectation that much of the content will involve analysis, but the student thinks that descriptive information is all that is needed, both will be disappointed with the results. The professor is disappointed with the quality of the papers received, and the student is disappointed in the grade assigned. The student goes to the campus learning center to complain that the grade was unfair, and the professor goes to the faculty development center to complain that the students are not performing well. In a sense, both assertions are correct because the expectations for student performance were not clearly communicated to the student. Today's students must be explicitly taught the difference between activities such as description, analysis, synthesis, and evaluation in the hierarchy of learning tasks. Without explicit instruction and clearly defined expectations, they will not be able to perform at the desired level.

\section{The Millennial Learner}

In the early to mid-1990s when institutions of higher education began to transform themselves from teacher-centered to learner-centered institutions, the focus shifted from the quality of the teaching to the quality of the learning that was occurring (Barr \& Tagg, 1995). When the emphasis shifted to the learner, the concept of the student as consumer began to emerge, and this, too, had significant implications for higher education.

The movie Field of Dreams has a well-known phrase: "If you build it, they will come." We now have in place what surely would have been considered a field of dreams by some educators-the nonelitist ones-a half century ago. We have built a vast system of higher education, and they are indeed coming-in record numbers (Baldwin, 2000). And students are not coming just for the love of learning. They are coming because they were promised something. This process has essentially created a carnival of credentialism. Students want to get their tickets punched. They want a certificate, a diploma, a degree, a title, something specific that will be their platinum card to the good life. An indication of this phenomenon is the decline in the percentage of students pursuing degrees in the liberal arts, including the sciences, and the increase in the percentage of students pursuing degrees in a pre-professional or technical field (Baldwin, 2000).

The financial rewards associated with attending college are indeed significant. According to Census Bureau figures (Reich, 2000), the aver- 
age income in 1998 of families headed by someone with only a high school education was $\$ 48,434$. That family income rose to $\$ 65,524$ when the bread winner had an associate's degree; jumped to $\$ 85,423$ with a bachelor's degree; and $\$ 101,670$ with a master's degree. A professional degree raised the family to an average income of $\$ 147,170$.

With so much at stake, and so many people hustling for a piece of the pie, students may not perceive themselves as having time for learning for the sake of knowledge, or for the thrill of discovery. The millennial learner is a bottom-line learner.

This was demonstrated in a recent conversation one of the authors had with a student who had been the valedictorian of her high school graduating class. The student had encountered sufficient problems with her university level science classes that she had decided to abandon her pre-med major-at least temporarily. She had decided to major in psychology, but wondered if she could hedge her bets by double majoring in a field not offered by this university. She would take those classes in another university across town, which had the appropriate department-but whose diploma carried, she thought, less luster. She was advised that taking some outside courses in a field of interest was a good idea, but that she might not be able to successfully pursue a double major at different institutions. Then, inevitably, she got to the bottom line: Would she ever find a job with just a psychology degree? Only when she was introduced to an actual psychology major with an actual job did she feel confident that her college degree in psychology would allow her to become gainfully employed.

Although students in the 1970 s were plenty ambitious about what job they would get, there appeared to be considerably less anxiety about the very prospect of making a living. Certainly, a liberal arts degree from a selective college was thought to guarantee employment. But then such a degree did not cost upwards of $\$ 120,000$, as can be the case today (Gose, 2000). Loans were not as universal as home mortgages and credit card balances-and, significantly, there were fewer first-generation college students, people for whom even the financing necessary for a local public college is a risky bet (Farrell, 1999). Of course students are anxious. Having so much to gain can be even more frightening than having little to lose.

So this creates a dilemma for the millennial educator. There is an old adage: Give a man a fish and he eats for a day; teach him to fish and he eats every day. Teachers believe that. When a grade school teacher encourages a child to sound out a word instead of immediately identifying 
it for him, she's teaching him to fish-by reading. Educators who want to facilitate student learning are handing out fishing rod kits. However, many students are looking for prepared seafood dinners to go. They might stand still for some microwaving instructions, but they have no interest in knowing how to catch it, clean it, or cook it.

In the Center for Minority Educational Affairs at Georgetown University, course tutors are assigned free of charge to students by request. First, however, a student must meet with an academic advisor, who will try to help him or her understand something about his or her own learning style, will inquire about the professor's teaching style, and will ask if the student has explored other resources, including attending professor's office hours and teaching assistants. Students will routinely listen to all the questions, nod, and ask: "Okay, can I have a tutor now?"

Students in higher education often view themselves as paying for the product, not the process. For some students, the goal is not the knowledge that results from learning but the rewards conveyed by demonstrating a temporary mastery of that knowledge.

It is, therefore, essential for educators to articulate the importance of learning as a process of self-discovery and growth. Because students may have so little knowledge and imagination about the connection between some traditional academic fields and jobs, and because both spheres are changing so fast, the skills of learning take on even greater significance.

\section{Technology}

We, in academe, must explicitly demonstrate the connection between what we do and what happens in the outside world. We do what we do because we love it. The vast majority of students we encounter will not follow in our footsteps. However, we must find a way to convey our passion to them so that they will develop the capacity to love what they do professionally. They must be taught that knowing or discovering how and why are much more important than simply knowing what (Handy, 1998). We owe them that. We owe it to ourselves.

Offering ourselves as examples of learners obviously becomes much more difficult with an increasing dependence on technology. On the one hand, the explosion of distance learning in all its forms may confound efforts to personalize the learning process. Such an environment demands an even more conscientious articulation of student learning goals. On the other hand, some students' dependence on technology-in particular on the Internet-liberates them from the presence of instructors-the 
older adults with whom they may wish to avoid contact as much as possible. But there are other factors to consider.

Unlike the Internet, the campus library occupies a specific physical location (or locations). Students should see the library as a resource that can never be replaced by electronic information resources. One advantage of such a place is simply the discipline involved, on a residential campus, in physically going to the library, so that one can concentrate in a dedicated study environment with fewer distractions.

In this environment, organization is imposed by the physical restrictions of space. In a library, there is a place for everything, and everything is in its place. It is possible to walk into the library and immediately find the reference desk; in close proximity are the black leather encyclopedias and green paperbacked Reader's Guide to Periodical Literature. Current newspapers are laid out on racks, older newspapers are stacked on shelves, and still older editions on microfilm. Bound volumes of magazine are in the stacks, with the older issues on microfiche or, now, on CD-ROM. In the stacks are rows and rows of books on a single subject-philosophy, Russian history, child psychology. Once you get there, you can just browse, three-dimensionally. You can hold the books, open them, flip through them, compare them. It could present a whole new learning style for anyone who might not ingest information so easily on a computer monitor.

In that physical world one can, in fact, judge a book by its cover. Scholarly abstracts look different from self-help books. It is impossible to mistake People magazine for the New England Journal of Medicine, or a small-press literary magazine for an undergraduate newspaper. An example of this occurred recently in a class one of the authors teaches. Some students completed a writing assignment in which they explored the realm of undergraduate fashion. The instructor's objective was for them to do a sociological literature search on the broad topic, and perhaps research some marketing theory. Instead, several students cited the same article from the Syracuse University student newspaper, an interview with an Abercrombie \& Fitch spokesperson who was on campus.

The very freedom granted by the Internet poses its greatest challenge, especially for the impatient millennial learner. On the Internet, it's all out there, all within reach. There are no boundaries and few distinctions. Everything about the Internet conspires to obscure the fact that all sources are not created equal. One can tailor a search to more authoritative databases and journals, of course. Yet when it was suggested to these students that they consult a reference librarian before they do 
their Internet search, their reaction was one of utter bewilderment. Why on earth would they want to do that when they could Yahoo their way to three or four reasonable-looking sites (and cites) in 20 minutes in their rooms at their convenience-in the middle of the night if necessary.

These habits require faculty to be familiar with such research techniques, even with the most common sites a given assignment is likely to lead to. For some, however, the Internet learning curve may prove too steep. Talk of online interactive syllabi, electronic discussion groups, chat rooms, or even email is sometimes stressful for faculty and causes some professors to mentally tune out the discussion and hope that all of this will eventually disappear (Sax, Astin, Korn, \& Gilmartin, 1999).

Still, this is a tremendous opportunity to teach explicitly what in the past was often taken for granted. That is, what difference does it make? Why is some information privileged over other information? Why is some more reliable, more authoritative? Why does the whole construction of human knowledge depend on a careful system of verification and accountability? Why is plagiarism considered such a heinous crime-not just copying (or downloading) someone else's work, but also sloppy citation, which is more likely when sources are floating in cyberspace with no context.

In other words, it is necessary to convince these skeptical students of what faculty know quite well and what has guided their professions: that learning is a dynamic, interactive, hands-on process. The key, really, has always been engagement.

\section{Learning Centers}

The challenge for faculty is developing instructional methodologies that will keep students mentally engaged in their own learning because students today seem to have a lower tolerance for less engaging pedagogical techniques. In recent years, teacher-centered lecturing has given way to collaborative learning, service-learning, problem-based learning, learning communities, residential colleges, and a number of other innovative techniques designed to engage the learner in the learning process (Tinto, Love, \& Russo, 1993). Faculty members are beginning to take seriously the mandate to move from the "sage on the stage" to become the "guide on the side." There are several reasons that the millennial learner is less tolerant of passive learning techniques.

First, more millennial learners are formally diagnosed as ADD or $\mathrm{ADHD}$, and there are many more distractions in their environment. Students in earlier decades were not being called to simultaneously talk on 
the cell phone, read their email, and study for a test, because the technology was not widely available.

Secondly, there is a significant increase in the amount of binge drinking occurring on college campuses. Wechsler, Lee, Kuo, and Lee (2000) reported that two of five university students (44\%), in a sample of 14,000 students at 119 four-year colleges, were binge drinkers in 1999. As might be expected, missing class and falling behind in schoolwork were significant problems experienced by binge drinkers. Tinto, Love, and Russo (1993) report that engaging pedagogies, such as learning communities, service-learning, and residential colleges, can significantly decrease the incidence of high-risk behaviors, such as binge drinking, on college campuses.

Finally, students lack basic study skills. The suggested reasons for the apparent decline of general study skills have been numerous. One example is the increasing use of high-stakes testing in 4th, 8th, and 12th, grades. McNeil (2000) writes about the effects of the Texas Assessment of Academic Skills (TAAS) test on the quality of learning in Texas schools.

When students' learning is represented by the narrow indicators of a test like the TAAS, teachers lose the capacity to bring into the discussion their knowledge of what students are learning. Test scores generated by centralized testing systems and the test-prep materials aimed at generating higher scores, are not reliable indicators of learning. (McNeil, 2000, p. 731)

Teachers have reported that the test preparation may actually hamper students' ability to read for meaning. They indicate that spending months on reading short passages and answering multiple-choice questions on these passages undermines their students' ability to read sustained passages of several pages. And because the material is meant to be forgotten soon after the questions have been answered, it is no wonder that the millennial student has difficulty with comprehension and retention of reading material in courses. Furthermore, the subjects that are not yet covered on high-stakes tests (science, arts, and social studies) are also affected because teachers in low-performing schools are required to drop instruction in those subjects and spend more time teaching for the math and reading tests. After all, it is the performance on these tests that will determine whether students are allowed to progress from one grade to the next, the rating of the school among its peers, and in some cases, even 
raises for administrators and teachers. It is no wonder that the millennial students will arrive on campus with a paucity of learning skills.

And that's where learning centers come in. These centers provide services and offer programs that teach students how to learn. Three techniques that have been employed at Louisiana State University with significant success are providing supplemental instruction (SI) in historically difficult courses, teaching the continuous process of learning (CPL) and intense study sessions, and the offering of the Absent Professor Program to faculty who must be away for a planned absence.

The SI program, conducted in universities throughout the United States and in several foreign countries, utilizes peer conducted collaborative learning sessions to help students in historically difficult classes $(D$, $\mathrm{F}, \mathrm{W}$ rates of $30 \%$ or higher). The sessions help students master course content while they develop and integrate effective learning and study strategies.

The continuous process of learning (CPL) and intense study sessions are learning tools that provide students with concrete strategies for improving their study skills. CPL teaches students a four-step process for success.

1) Pre-read or read material before class

2) Go to class and actively participate in the lecture

3) Review and process class notes as soon after each class as possible

4) Utilize intense study sessions to combat procrastination

The intense study sessions are 60-minute sessions consisting of the following segments:

1) 2-5 minutes: Set goals for the next 40 minutes

2) 35-38 minutes: Accomplish the goals

3) 10 minutes: Review what was studied

4) 10 minutes: Take a break

The absent professor program, conducted jointly with the LSU Career Center, provides speakers for classes whose instructors must miss class for reasons such as professional travel, family emergencies, etc. A member of the Learning Center faculty, or a member of the Career Center staff, conducts a workshop on the topic of the faculty member's choosing. Popu- 
lar topics have included résumé preparation, interviewing skills, test preparation, and techniques for mastery learning in chemistry.

\section{Conclusion}

It is important that learning strategies be taught by all faculty members, not just learning center faculty. Instructional development centers can play an important role in teaching faculty and teaching assistants how to do that. Liaisons between the campus learning center and the faculty development center can conduct joint workshops for faculty on effective strategies for teaching students how to learn. In this new millennium, that is the sort of effort that will inevitably lead to better education for all students.

\section{REFERENCES}

Barr, R. B., \& Tagg, J. (1995, November/December). From teaching to learning: A new paradigm for undergraduate education. Change, 13-25.

Baldwin, J. (2000). Why we still need liberal arts learning in the new millennium. Education Digest, 66 (4), 4-9.

Braxton, J. M., Milem, J. F., \& Sullivan, A. S. (2000). The influence of active learning on the college student departure process: Toward a revision of Tinto's theory. Joumal of Higher Education, 71, 569-590.

Farrell, C. (1999). Loans for college don't have to crush grads. Business Week, $3637,147$.

Gose, B. (2000). Measuring the value of an ivy degree. Chronicle of Higher Education, 46(19), A52-A53.

Handy, C. (1998). A proper education. Change, 30 (5), 13-19.

McNeil, L. M. (2000). Creating new inequalities: Contradictions of reform. Phi Delta Kappan, 80, 728-734.

Reich, R. B. (2000). How selective colleges heighten inequality. Chronicle of Higher Education, 47 (3), B7-B10.

Sax, L. J., Astin, A. W., Korn, W. S., \& Gilmartin, S. K. (1999). The American college teacher: National norms for the 1998-99 HERI faculty survey. Los Angeles, CA: University of California, Los Angeles, Higher Education Research Institute. 
Schilling, K. M., \& Schilling, K. L. (1999). Increasing expectations for student effort. About Campus, 4 (2), 4-10.

Tinto, V., Love, A. G., \& Russo, P. (1993). Building community. Liberal Education, 79, 16-21.

Wechsler, H., Lee, J., Kuo, M., \& Lee, H. (2000). College binge drinking in the 1990s: A continuing problem. Journal of American College Health, 48 (10), 219-226.

Contact:

Saundra Y. McGuire

Louisiana State University

B-31 Coates Hall

Baton Rouge, LA 70803

(225) $578-6749$

Email: smcguil@lsu.edu

Dennis A. Williams

Georgetown University

Box 571087

Leavey Center

Washington, DC 20057-1003

(202) 687-4054

(202) 687-7731 (Fax)

Email: daw6@gunet.georgetown.edu

Saundra Y. McGuire is Director of the Center for Academic Success at Louisiana State University and former Director of the Learning Strategies Center at Cornell University. She is also Associate Dean of University College and Adjunct Professor of Chemistry at Louisiana State University. McGuire writes ancillary materials for general chemistry textbooks and presents workshops for university students and faculty. Her interests include improving learning strategies used by university students and reform of science teaching methods.

Dennis A. Williams is Director of the Center for Minority Educational Affairs (CMEA) and a professorial lecturer in English at Georgetown University. CMEA is the only provider of comprehensive academic support at the university. Previously he directed the Learning Skills Center at Cornell University and was a senior lecturer in the John S. Knight Writing Program there. Holder of the MFA degree from the University of Massachusetts, Williams is also a novelist, essayist, and journalist. 